\title{
Conceptual and methodological aspects in the study of hospitalizations for ambulatory care sensitive conditions
}

\author{
Aspectos conceituais e metodológicos no estudo \\ das hospitalizações por condições sensíveis à atenção primária
}

Fúlvio Borges $\mathrm{N}$ edel ${ }^{1}$

Luiz Augusto Facchini ${ }^{2}$

J oão Luiz Bastos ${ }^{3}$

M iguel M artín-M ateo ${ }^{4}$
${ }^{1}$ Departamento deBiologiae Farmácia, Curso de

M edicina, Programa de PósGraduação em Promoção da Saúde, Grupos de Pesquisa em SaúdedaAmérica eÁfrica Latinas, Universidadede Santa Cruz do Sul. Av. Independência 2.293/Prédio 42/sala 4206, Bairro

Universitário. Santa Cruz do Sul RS.

fulvionedel@yahoo.com.br ${ }^{2}$ Departamento de M edicina Social, Faculdade de Medicina, Universidade Federal de Pelotas.

${ }^{3}$ Departamento deSaúde Pública, Centro de Ciências da Saúde, Universidade Federal de Santa Catarina.

${ }^{4}$ Grups de Recerca d'Amèrica

i Àfrica Llatines, Unitat de Bioestadística, Facultat de

M edicina, Universitat

AutònomadeBarcelona.
Abstract Hospitalization rates for Ambulatory CareSensitive Conditions have been used to assess effectiveness of the first level of health care. From a critical analysis of related concepts, wediscuss principles for selecting a list of codes and, taking the example of the Brazilian Family Health Program, propose a methodological pathway for identifying variables in order to inform statistical models of analysis. We argue that for the indicator to be comparable between regions, disease codes should be selected based on sensitivity and specificity principles, not on observed disease frequency. Rates of hospitalization will be determined, at a distal lev$\mathrm{el}$, by the socio-economic environment and their effect on the social and demographic structure. Timely and effective care depends on the organization of health services, their availability and access barriers, which depend on the ways health and related technology are conceptualised and on their adherence to the biomedical model or to the Primary $\mathrm{H}$ ealth Care $(\mathrm{PHC})$ principles; performance indicators of the health system will be the proximal determinants. This indicator is potentially useful for primary care evaluation. The historical reconstruction of $\mathrm{PHC}$ improves the analysis of the indicator variability.

Key words Primary health care, Family health program, Outcomeassessment (health care), H ospital information systems, $\mathrm{H}$ ealth systems
Resumo Astaxas dehospitalização por condições sensíveis à atenção primária são um indicador da efetividade do primeiro nível de atenção à saúde. Partindo de breve revisão crítica, este artigo discute princípios para a seleção de códigos de internação por essas causas e, com o exemplo do Programa Saúde da Família, propõe um modelo teórico para a seleção de variáveis para análise estatística. A comparabilidade inter-regi onal do indicador depende da seleção de códigos de doenças baseada em princípios de sensibilidade e especificidade, não na frequência da doença. As taxas de hospitalização serão distalmentedeterminadas pela situação socioeconômica e seu efeito sobre a estrutura social edemográfica; em nível intermediário, pela organização dos servi ços de saúde, sua disponibilidade e barreiras de acesso, que por sua vez dependem dos conceitos de saúdeetecnologia relacionada adotados e de sua aproximação ao modelo biomédico ou aos princípios da atenção primária à saúde (APS) ; indicadores de desempenho do sistema de saúde serão os determinantes proximais. 0 indicador é potencialmente útil para a avaliação da atenção primária. A reconstrução histórica da APS contribui para a análise da variabilidade do indicador.

Palavras-chave Atenção primária à saúde, Programa Saúde da Família, Avaliação de resultados (cui dados de saúde), Sistemas de informação hospitalar, Sistemas de saúde 


\section{Introduction}

Since the historic Declaration of Alma-Ata ${ }^{1}$ in 1978, Primary H ealth Care (PH C) achieved consensus as a proposal for an efficient health care organization, whose aim is to attain the principles of equity, health promotion and protection, continued care, integrality and universality ${ }^{2,3}$. This contrasts with the model of the specialist and hospital-centred system which focuses on the biologic aspects of disease and patient, and is a great consumer of 'hard' biomedical technology. Therefore, PHC appears as a fundamental element of health reform in different countriest. In Brazil, $\mathrm{PHC}$ is the basis for the Brazilian N ational Health System, the Sistema Único de Saúde (SUS), serving as the first instance of careand, in theory at least, a structuring and orienting element of care ${ }^{5}$. In 1994, five years after the SUS was started and in the face of difficulties with its implementation, the Brazilian M inistry of $\mathrm{H}$ ealth launched the Family Health Program (FHP) Programa Saúde da Família (PSF) as a strategy for promoting PHC in municipalities ${ }^{6}$.

But welack evaluation and monitoring of health care. Brazil is on its beginning of such a practice, and still there are few research studies on the impact of health system over population health. Among the possibilities of PHC assessment, hospital admissions for Ambulatory Care Sensitive Conditions (ACSC) areused as an indirect indicator of effectiveness at this level of the system ${ }^{7-14}$. This indicator groups together different causes of hospital admission for conditions typically managed in the first level of health care, i.e. those for which the need for hospitalization could havebeen avoided with ambulatory and non-specialized care.

Despite the relevance of the ACSC in the assessment of basic health care, with increasing recognition on the international scene ${ }^{15-20}$, its use in Brazil still remains limited ${ }^{21,22}$. Also, there are yet few Brazilian studies published on scientific journals ${ }^{23}$, but a bill from the Health M inistry publishing the Brazilian list of codes for Ambulatory Care Sensitive Conditions (Lista Brasileira de Internações por Condições Sensíveis à Atenção Primária, Portaria M S no 221, de 17/4/2008) and works presented in thelast Brazilian Family M edicine Society (Sociedade Brasileira de M edicina de Família e Comunidade) and World Epidemiology congresses, show this as an emerging theme.

N onetheless, thereis diversity on theconstruction and use of the indicator around the world, expressed by the variety of lists of codes and variables considered in statistical explanatory model $s^{24}$. Thesefindings deserve synthesis and discus- sion in order to conform a comparable set of disease codes. Furthermore, this synthesis should focus on the statistical analysis and further discussion on variables related to the health system. So, the theoretical and methodological development of thisindicator in the Brazilian context may contribute not only towards an improvement in the assessment of the PHC in Brazil, but also towards a comparison between countries, a demand set forth by international organization $\mathrm{s}^{25}$.

This paper has two principal aims: (1) to discuss the principles for selecting a list of ACSC disease codes in order to allow inter-regional comparisons of PHC effectiveness, and (2) to propose a conceptual framework for selecting categories of analysis in studies with this indicator, taking the case of FH P in Brazil.

These objectives were approached by a brief critical review of central concepts, such as PHC, model of care, and ACSC. The common axis in thosetexts, which conceptually discuss PHC and model of care $e^{4,5,26,27}$, is their affiliation to the principles of Alma-Ata, a critical perspective on the biomedical model and a distinction between ambulatory care and primary health care.

\section{Primary health care and model of care}

The organizational strategy of a health system based on primary care figures, for the first time, in the report presented by Lord Dawson to the British M inister of Health in $1920^{28}$. In an attempt to meet demands for greater efficiency in the health system, Dawson proposed an organization based on the geographical distribution of the population, around health centres, in which the complexity is not related to the technology but to the patient environment. These centres would be responsible for the provision of primary care, be it home-based (effectively the first level of care) or offered at thehealth centre. $M$ ore severe, urgent or clinically complex cases would be referred to other centres, with more specialized biomedical technology. The primary care centres would be located in small territorial centres with patient registration exclusively available to residents in the area and connected, in a radial way, to the specialist centres.

In Alma-Ata, the World Health Organization (WHO) maintains the principles of the Social M edicine movement ${ }^{29}$ and adds them to Dawson's proposal. However, 25 years after that Conference and despite its political and technical acceptance, it was clear that its conceptual framework was scarcely used: in practice, among sparse 
and isolated successful experiences, the intended $\mathrm{PHC}$ was often no more than the primary level of care for specific procedures resembling the selective primary care, a far cry from the principles agreed upon in the Soviet Union ${ }^{30}$. Shaped by the reality of each country, its concept was interpreted according to different visions of health and society and it was applied according to health budget resources and political possibilities s, $30,31^{\text {. }}$ $\mathrm{N}$ evertheless, we can see over 30 years from Alma-A ta that, in spite of budget restrictions carried out on the neoliberalism wage, PHC have been expanded in both reach and poor countries, at atimethat there is increasing evidence of its benefits on people health and health expenditure ${ }^{3,32}$.

The Family H ealth Program is a health policy and, as such, its accomplishment is (re) achieved day after day, representing the result of a complex power dispute $e^{27,33}$. It is the result of the PHC policies that will enablethem to legitimizetheir theory and health practice. Independently of the concept and organization of the first level of care- ambulatory care or PHC - , it is expected to find solutions to approximately $85 \%$ of health problems.

Its impact can beassessed, among other ways, by one of the most objective and valued criteria for primary care: the resolvability at local level of the most common reasons for seeking medical attention 3,5,28,31,34. An indicator like the hospitalizations for ACSC can be useful for this purpose.

\section{Ambulatory care sensitive conditions (ACSC)}

ACSC are diseases typically managed at the first instance of care. The underlying premise for the use of hospitalizations for ACSC as an indicator of effectiveness of the first level of care is that these represent its bad performance. Insufficiencies at this level of the system make hospitalization necessary for health problems which would not occur or would not be aggravated to the point of requiring hospitalization, with timely and effective care $8,9,16,21,22,24$.

The concept arose at the end of the 1980s in the United States, a country to which the majority of studiesare restricted, followed by Canada, particularly until the turn of this century ${ }^{35,36}$. Studies with the indicator have been gaining momentum in Spain ${ }^{10,13,16,24,37,38}$, Australia1 ${ }^{14,39}$, New Zealand ${ }^{17}$ and the United Kingdom ${ }^{40}$ and are beginning to appear in Brazi|21-23,41. Despite the criticism that determinants of the onset of disease, of health service and therapeutics access fall outside the re- sponsibilities or possibilities of primary care services, and that the variability observed in therates of hospital admission is strongly determined by clinical uncertainty, patient conditions, hospital medical practice and hospital admission policies $^{9,16,42}$, it is reasonable to think that PHC can avoid or decrease the number of hospital admissions for a group of specific causes.

Thelist of causes varies among studies. Some larger ones $16,17,21,24,41$ as well as the Brazilian list mentioned include diseases preventable by vaccination, congenital syphilis, tuberculosis, nutritional deficiencies, iron deficiency anaemia, convulsions, ear infectionsand respiratory problems, ulcers and perforated appendicitis, urinary infections, pelvic inflammatory disease, cellulite, growth problems, hypertension, heart failureand diabetes, etc. Others, briefer in content $9,15,23,35$, focus on the most common causes of admission among the ACSC.

Generally, the results found have displayed higher rates of admission for ACSC among the lower income population, poorer communities and those with low schooling levels $s^{7,9,13,35,41,43,44}$, varying according to specificities of the health services available. Differences are less marked where provision of health care is free or where access is guaranteed, such as in Canada ${ }^{35,44}$, Spain ${ }^{10,13,16}$ and France ${ }^{19}$, or when the need for medical training facilitates access for populations of low income who normally have no access to specific health care benefits, such as surgical residency programs in the United States ${ }^{9}$.

\section{Towards a comparable list of causes}

It can be said that, to be considered ACSC, an illness depends fundamentally on two principles: (1) any hospital admission considered avoidable or whose rates can be decreased through actions typically treated at the first level of care should be included in the indicator (sensitivity principle); and (2) admissions for conditions less sensitive (or unrelated) to actions of the primary level of care should not beincluded in theindicator (specificity principle).

When considering an avoidable episode, the indicator deals with an object in constant change, sincethepreventability is contextualized and characteristic of each historical period. Different contexts at the same moment of time can consider preventability in different ways, which can compromise the usefulness of the indicator. Therefore, the definition of lists of potentially avoidable hospitalizations for ACSC is a point of 
concern in thetheoretical-methodological development of the indicator.

For the definition of lists of causes to be considered ACSC, Caminal et al. ${ }^{13}$ suggest local validation studies of the indicator to adjust this to particularities of the organization of care, which condition access and patient course within the health system. It is possible that local protocols lead to hospitalization or specialized care for a determined ACSC. In this case, obviously, these admissions cannot be attributed to the PHC and theindicator loses validity for serviceassessment. However, it does not lose validity for assessment of policies, as these protocols represent a form of organization of care for problems which (in other places, at least) are considered typical of the first level of care. To be externally comparable, the indicator should consider the same disease codes, whatever their occurrencein any specific region. If so, the indicator will allow comparison between regions with different protocols, measuring the impact of health policies on primary care.

In this sense, the main purpose of local validation studies would bethegeneration of a basic consensual list of ACSC to be used in regional comparisons, to which specific causes of local interest could, perhaps, be added. For the analysis of impact of PHC policies, on theother hand, it is highly desirable that the indicator allows comparability between countries and regions around the world. Such an international list would be based on the sensitivity and specificity principles outlined above, and could take into account the lists of codes used in different countries. Thefact that themost prevalent ACSC arenot the samein different countries and continents would not be alimiting factor provided that those principles are preserved.

This logic is similar to that adopted in the studies of Burden of Disease, in which the description of the most important conditions in each location is stimulated, but all the causes are taken into account ${ }^{45}$. In this situation, the appropriate decision seems to be that of including among the ACSC those causes which - according to current medical opinion - arein line with the principles of indicator sensitivity and specificity, independently of their occurrence or local organization of care. This both for pragmatic reasons - the indicator comparability - as well as for a principle of equity - if the hospitalization for a specific cause can be avoided for people somewhere in the world, it is fair that it is avoided for all people everywhere in the world.

Therefore, two questions are presented for selection of causes to be considered ACSC: (1) if, given the technological conditions and current knowledge, thehospitalization for a specific cause can be avoided; (2) if - for these causes in which hospitalization is avoidable - the necessary actions to avoid admission are theresponsibility of the first level of care.

As a result, the indicator does not assess the quality of the medical act that leads to hospitalization. It is important to highlight that adapting a therapeutic approach to the patient's condition and surroundings - an example of good medical practice - can increase rates of hospitalization for ACSC, when the surroundings do not permit treatment at home (we should appoint that nevertheless therapeutics prescription in PHC typically occurs in the PHC centre, treatment is actually carried out at home). This in no way invalidates theindicator, nor will it mean, per se, that in certain health centres the quality of care offered is worse, as some Family Doctors fear ${ }^{42}$. On the contrary, it will emphasize the need to discuss and adapt the organization of PHC and its interaction with other instances of the health system or sectors of the State- for example, social assistance, day care, guest/visitor accommodation, day-hospitals, transport assistance services etc.

\section{Building the framework of analysis}

It should be clear that the indicator intends to assess theimpact of health policiesand programs, not the actions carried out to adapt the clinic to the patient's condition (i.e. medical practice). Consequently, the recommended smallest unit of analysis will bethe census tract or thehealth care centrein theindividual's residential area. In Brazil, with the variables available in the SU S's System of H ospital Information - Sistema de Informação Hospitalar do SUS (SIH/SUS) - , this will bethemunicipality.

Clusters of municipalities (or other units of analysis) showing high and low rates of ACSC are compared according to the characteristics associated with these clusters. Among these characteristics arethe effectiveavailability of servicesand their adequacy to the ways in which the population is organized and to the situations individuals are faced with. In this sense, the seminal work by Billings and Teicholz ${ }^{7}$ excludes "the lifestyles under the patient's control (smoking, alcohol, drug abuse, nutrition, obesity, etc.) and the 'adequacy' of [hospital] admission" from the analysis.

This means that, in characterizing the study object, those aspects relative to the clinical condition of the patient and its possibilities for therapeutic accomplishment, in the concretesituation 
in which doctor and patient find themselves on a day-to-day basis, are referred to the health system. The theoretical framework will focus on the political and social context responsible for the social structures which lead to the organization of the health system and allow (or not) access of different population groups to quality health care.

Categories such as "theroleof theState", "government proposals" and "system organization" should be highlighted as they shape the context of the health policies. Their relationship is discussed through the "coherence postulate" (Figure 1), by M ario Testa ${ }^{27}$. He claims that there is a necessary relationship between the government proposals and methods, as well as between proposals, methods, and the organization of health facilities. The organization of the system and related institutions - where care is provided - is determined, at micro level, by the government proposals and the method to achieve them. At macro level, the organization is determined by history, and history also determines the role of the State and the theory to justify it. The only category that does not appear to be determined by another is history, but history can be seen as the result of all the categories (including its own) being constructed over time. Also, at the micro level and on its relation to history, each determi- nation force suffers a reaction of less intensity, which Testa calls "conditioning".

Within such complexity, it is difficult to build a statistical model of analysis. But, through this approach and with the aid of the'postulate' diagram, we can organize appropriate categories of analysis of the indicator in an acceptable manner to select study variables and to better interpret findings.

Taking the example of Family Health Program, the "postulate" helps to understand how Family Health is shaped in Brazil, according to its historical circumstances, in a clash between health models and public/private relations. The impact of PHC on admissions for ACSC depends fundamentally on aspects related to organization of care, determined by themunicipality'shistory and by the local management of health, which, in turn, depends on the organization of the SUS at the higher levels of management.

So, broad analytical categories of these studies in Brazil, could be:

- administrative departments of the country or state, both for their cultural characteristics and historic antecedents as for the underlying organization of theSUS;

- size of town and urban growth;

- age (time of town's existence and of the creation of the Municipal Secretary of $\mathrm{H}$ ealth);

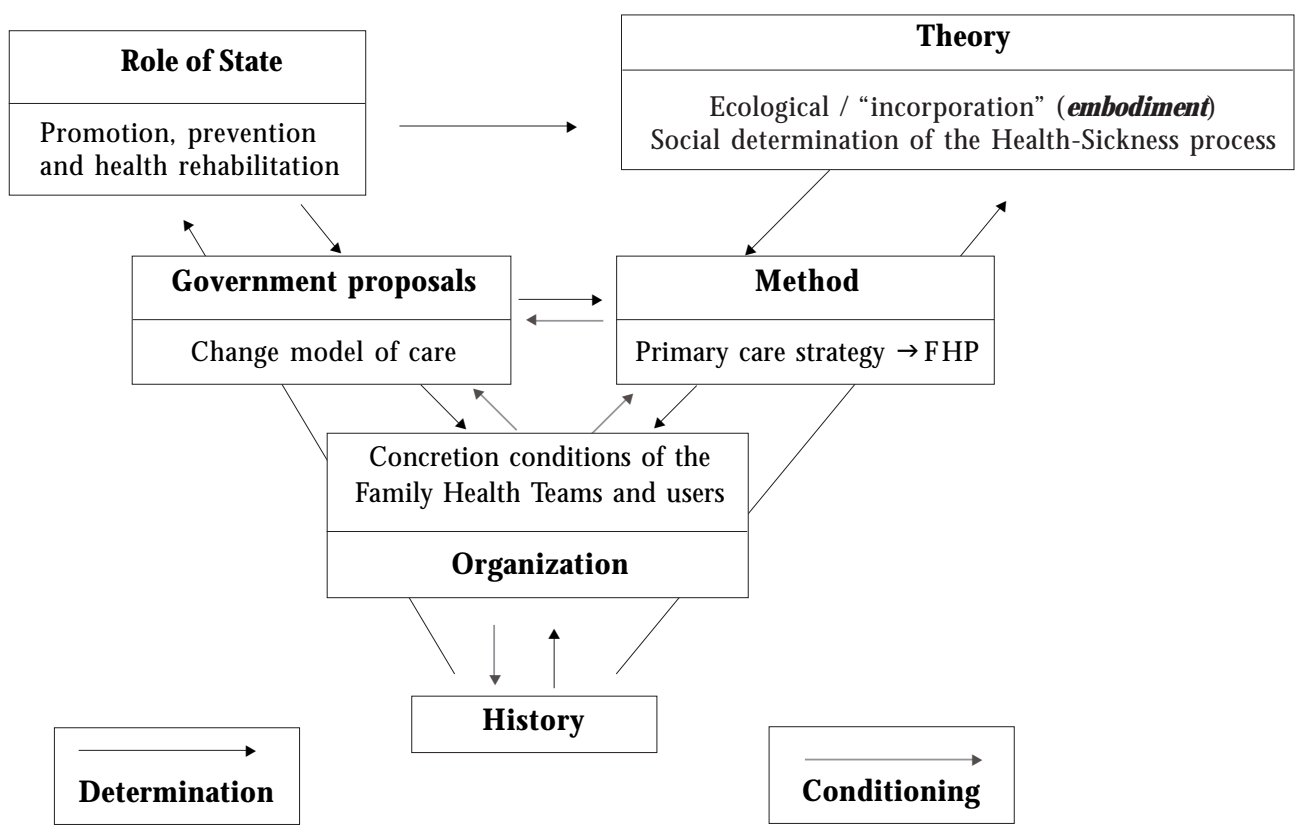

Figura 1. Use of the postulate of coherence ${ }^{27}$, for analysis of the Family Health Program (Programa Saúde da Família - PSF). 
- inclusion or proximity to a metropolitan region;

- equity (socio-economic indicators);

- care model (structureand primary careperformanceindicators; undergraduatecourses in the health sciences; admission in teaching hospitals);

- time and coverage of PSF.
Following this, in Box 1 we detail the above mentioned categories, and the level of analysis for a mixed model. Starfield ${ }^{46}$ suggests carrying out multilevel analyses in a broad context, comparing characteristics of groups (or regions, in our case) to which the individuals belong. It is important to highlight that the groups who will

Box 1. Categories for analysis and levels of groupings in a mixed model for assessment of hospitalizations for ambulatory care sensitive conditions in Brazil.

\begin{tabular}{|c|c|c|}
\hline \multicolumn{2}{|r|}{ Groupinglevel } & Categories for analysis* \\
\hline 7 & $\begin{array}{l}\text { Region in the } \\
\text { country }\end{array}$ & $\begin{array}{l}\text { M acro-economic and macro-structural, demographic and social variables, } \\
\text { distribution and characteristics of services and health work forces, financial } \\
\text { and structural incentives for health organization, period of deployment and } \\
\text { PSF coverage }\end{array}$ \\
\hline 6 & State & $\begin{array}{l}\text { M acro-economic and macro-structural, demographic and social variables, } \\
\text { distribution and characteristics of services and health work forces, financial } \\
\text { and structural incentives for health organization, period of deployment and } \\
\text { PSF coverage, budgetary resources spent on health, state health policies, } \\
\text { training and promotion of scientific debate in health, State Counsel of } \\
\text { Health performance }\end{array}$ \\
\hline 5 & $\begin{array}{l}\text { Macro-region of the } \\
\text { state }\end{array}$ & $\begin{array}{l}\text { M acro-economic and macro-structural, demographic and social variables, } \\
\text { distribution and characteristics of services and health work forces, financial } \\
\text { and structural incentives for health organization, period of deployment and } \\
\text { PSF coverage, political liaisons among towns, existence and performance of } \\
\text { M acro-Regional Health Counsels }\end{array}$ \\
\hline 4 & $\begin{array}{l}\text { Regional Health } \\
\text { Coordenation / } \\
\text { Delegacy (CRS/DRS) }\end{array}$ & $\begin{array}{l}\text { M acro-economic and macro-structural, demographic and social variables, } \\
\text { distribution and characteristics of services and health work forces, financial } \\
\text { and structural incentives for health organization, period of deployment and } \\
\text { PSF coverage, training and promotion of scientific debate in health, } \\
\text { participation in training, interaction of CRS/DRS with municipalities, } \\
\text { discussion of data generated by the SIAB with municipalities }{ }^{(a)} \text {, existence } \\
\text { and performance of Regional Health Counsels }\end{array}$ \\
\hline 3 & Town & $\begin{array}{l}\text { M acro-economic and macro-structural, demographic and social variables, } \\
\text { distribution and characteristics of services and health work forces, financial } \\
\text { and structural incentives for health organization, period of deployment and } \\
\text { PSF coverage, characteristics of municipal health management, especially } \\
\text { Family Health, training and promotion of scientific discussion in health, } \\
\text { participation in training, performance of Municipal Health Counsel }\end{array}$ \\
\hline 2 & Health Centre (HC) & $\begin{array}{l}\text { Economic, demographic, social and structural variables of the population, } \\
\text { district facilities (schools, transport, sanitation and urbanization, leisure, } \\
\text { etc.), team participation in training, structural and organizational } \\
\text { characteristics of the Health Centres (HC) and Health Team, of local } \\
\text { management of the HC and of work in health, variables of performance, } \\
\text { community participation, existence and performance of Local Counsel of } \\
\text { Health and Residents' Associations }\end{array}$ \\
\hline 1 & $\begin{array}{l}\text { Health } \\
\text { micro-area }\end{array}$ & $\begin{array}{l}\text { Economic, demographic, social variables, environmental characteristics, } \\
\text { urbanization, type of residence }\end{array}$ \\
\hline
\end{tabular}

* The typical categories of each analysis level are in bold.

(a) SIAB - Sistema deInformação da Atenção Básica - System of Information of Basic Care. 
form the level of analysis in a mixed model context are constituted by the health services and by theorganizational-administrativedivision of the health system under assessment, and never by other groupings related to the user. That is to say that, when taking into account that the structures and their influence depend on the place in which the cases are produced, an analysis of mixed models should becarried out with theplace or unit of measurement as a random factor.

Hence, the variables analysed in studies on hospitalizations for ACSC should describe aspects of the history and organization of the local health system, enabling an understanding of the inclination towards or away from the biomedical model. Data on structureand organization of work in health, as well as political texts from the local medical associations and epidemiological reports may provide this picture. Organization of services can also be determined by local sociocultural characteristics associated with the foundation and development of the municipality, its size and growth, as well as the possibility of investments on the part of public power and the average and median income of the population (because equity is associated with the best levels of population health ${ }^{46}$ and, presumably, with best performance of the health system). Such variables can be organized in accordance with the diagram in Figure 2.

As most of this information is neither registered on secondary databases nor available from classical epidemiological studies, qual itativestudies- sociological, organizational and ethnographic - would be extremely useful in order to construct a more detailed and complete picture of the underlying variability of admissions in the different centres under investigation.

\section{Conclusion}

Rates of hospitalization for ACSC are potentially useful as an indicator of theimpact of PHC. They easily facilitate analysis of the whole country as well as of states and regions, comparing clusters of municipalities with high or low rates and their characteristics.

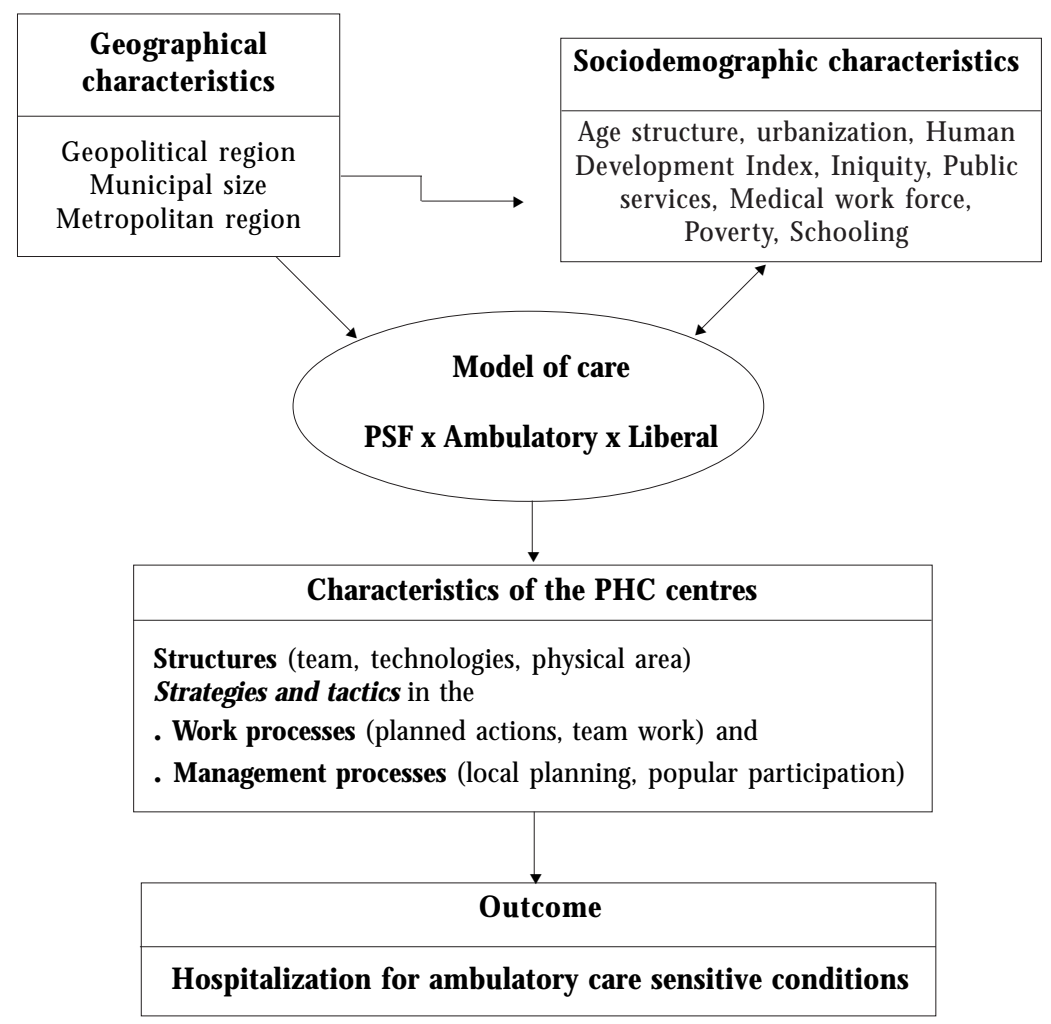

Figura 2. Theoretical framework of the effectiveness of primary care assessed by health indicators. 
It is desirable to move toward an international list of codes in order to provide international comparability to the indicator. This list should be comprehensive, as is PHC, but should not disregard on the specificity principle.

The historical recovery of the concept of PHC and its application in different countries, particularly through the PSF in Brazil, allows the elabora- tion of categories of analysis for the explanation of variability of ACSC hospital discharges, offering useful information for the development of actions to improve the population's health status.

Integrating different fields of public health research can provide better information and understanding of health policies impact on population health.

\section{Collaborators}

Fúlvio Nedel was responsible for the article conception, bibliographic review and first draft of article. All theauthors participated on the subsequent versions and agree with the final version.

\section{Acknowledgements}

Preparation of this article was facilitated by a scholarship provided by the Brazilian Coordenação de Aperfeiçoamento de Pessoal de Nível Superior (CAPES) for the first author (Nedel), which made it possible for him to study for one year at the Biostatistics Unit, in the Faculty of M edicine of the Universitat Autònoma de BarceIona, Spain. Presented to the Programa de PósGraduação em Epidemiologia da Universidade Federal de Pelotas [Program of Graduate Studies in Epidemiology of the Federal University of Pelotas] for obtaining PhD degree.

\section{References}

1. Organização Mundial da Saúde. Conferencia Internacional sobre Atención Primaria de Salud: Declaración de Alma-Ata. Genebra: OM S; 1978.

2. Starfield B. Atenção primária: equilíbrio entre necessidades de saúde, serviços e tecnologia. Brasília: U NESCO/M inistério da Saúde; 2002.

3. World Health Organization. The world health report 2008: primary health care now more than ever. Geneva: WHO; 2008.

4. U ribe-Oyarbide JM. Educar y curar: el diálogo cultural en atención primaria. Madrid: Ministerio de Cultura; 1995.

5. Mendes EV. Distrito sanitário: o processo social de mudança das práticas sanitárias do Sistema Ú nico de Saúde. São Paulo: Hucitec; 1999.

6. Facchini LA, Piccini RX, Tomasi E, Thumé E, Silveira DS, Siqueira FV, Rodrigues MA. Desempenho do PSF no Sul e no Nordeste do Brasil: avaliação institucional e epidemiológica da Atenção Básica à Saúde. Cien Saude Colet 2006;11(3):669-681.

7. Billings J, Teicholz N. Uninsured patients in District of Columbia hospitals. Health Affairs (M illwood) 1990; 9(4):158-165.

8. Weissman JS, Gatsonis C, Epstein AM. Rates of avoidable hospitalization by insurance status in Massachusetts and Maryland. JAM A 1992; 268(17): 2388-2394.

9. Billings J, Zeitel L, Lukomnik J, Carey TS, Blank $A E$, N ewman $L$. Impact of socioeconomic status on hospital use in New York City. Health Aff (M illwood) 1993; 12(1):162-173.

10. Casanova C, Colomer C, Starfield B. Pediatric hospitalization due to ambulatory care-sensitive conditions in Valencia (Spain). Int J Qual Health Care 1996; 8(1):51-59.

11. Sanderson C, Dixon J. Conditions for which onset or hospital admission is potentially preventable by timely and effective ambulatory care. J Health Serv Res Policy 2000; 5(4):222-230. 
12. Brown AD, Goldacre MJ, Hicks N, Rourke JT, M cMurtry RY, Brown JD, Anderson GM. Hospitalization for ambulatory care-sensitive conditions: a method for comparative access and quality studies using routinely collected statistics. Can J Public Health 2001; 92(2):155-159.

13. Caminal Homar J, Starfield B, Sanchez Ruiz E, Hermosilla Perez E, Martin M ateo M. La Atencion Primaria de Salud y las hospitalizaciones por Ambulatory Care Sensitive Conditions en Cataluna. Rev Clin Esp 2001; 201(9):501-507.

14. Ansari Z, Carson N, Serraglio A, Barbetti T, Cicuttini F. The Victorian Ambulatory Care Sensitive Conditions study: reducing demand on hospital services in Victoria. Aust Health Rev 2002; 25(2):71-77.

15. Niti M, N g TP. Avoidable hospitalisation rates in Singapore, 1991-1998: assessing trends and inequities of quality in primary care. J Epidemiol Community $\mathrm{H}$ ealth $2003 ; 57(1): 17-22$.

16. Bermudez-Tamayo C, Marquez-Calderon S, Rodriguez del Aguila M M, Perea-M illa Lopez E, Ortiz Espinosa J. Caracteristicas organizativas de la atención primaria y hospitalización por los principales ambulatory care sensitive conditions. Aten Primaria 2004 15; 33(6):305-311.

17. Dharmalingam A, Pool I, Baxendine SJS. Trends and patterns of avoidable hospitalisations in $\mathrm{New}$ Zealand: 1980-1997. N Z M ed J 2004; 117(1198):U 976.

18. Bindman $A B, C$ hattopadhyay $A, O$ smond $D H$, Huen W, Bacchetti P. The impact of Medicaid managed care on hospitalizations for ambulatory care sensitive conditions. Health Serv Res 2005; 40(1):19-38.

19. Gusmano MK, Rodwin VG, Weisz D. A new way to compare health systems: Avoidable Hospital Conditions in M anhattan and Paris. Health Affairs ( $M$ illwood) 2006; 25(2):510-520.

20. Rizza P, Bianco A, Pavia M, Angelillo IF. Preventable hospitalization and access to primary health care in an area of Southern Italy. BMC Health Serv Res 2007; 7(1):134.
21. Fundação João Pinheiro. Centro de Estudos Econômicos e Sociais. Atenção básica à saúde em M inas Gerais: desigualdades na distribuição de recursos financeiros e na prestação de serviços básicos após a introdução do Piso da Atenção Básica(PAB). Belo Horizonte: Fundação João Ribeiro; 2003.

22. Mendes EV. A atenção primária à saúde no SUS. Fortaleza: Escola de Saúde Pública do Ceará; 2002.

23. Dias-da-Costa JS, de Borba LG, Pinho MN, Chatkin M. Quality of primary care as measured by preventable hospitalizations in the South of Brazil. Cad Saude Publica 2008; 24(7):1699-1707.

24. Caminal J, M undet X, Ponsa J, Sanchez E, Casanova $C$. Las hospitalizaciones por ambulatory care sensitive conditions: selección del listado de codigos de diagnostico validos para Espana. Gac Sanit 2001; 15(2):128-141.

25. Atun R. What are the advantages of restructuring a health care system to be more focused on primary care services? Copenhagen: WHO Regional Office for Europe; 2004.

26. Comelles J. La utopía de la atención integral de salud: autoatención, práctica médica y asistencia primaria. In: Alvarez-Dardet C, Porta M, editors. Revisiones en Salud Pública Barcelona: M asson; 1993. p. 169-192.

27. Testa M. Pensar en salud. Buenos Aires: Lugar; 1989.

28. Organización Panamericana de la Salud. Informe Dawson sobre el futuro de los servicios médicos y afines, 1920. Informe provisional presentado al Ministerio de Salud de la Gran Bretaña en 1920 por el Consejo Consultivo de Servicios M édicos y Afines. Publicación Científica no 93. Washington, D.C.: Organización Panamericana de la Salud; 1964.

29. Rosen G. Da polícia médica à medicina social: ensaios sobre a história da assistência médica. Rio de Janeiro: Graal; 1980.

30. Cueto $M$. The origins of primary health care and selective primary health care. Am J Public Health 2004; 94(11):1864-1874. 
31. Organização Pan-Americana de Saúde. Organização M undial da Saúde. Atenção primária de saúde nas Américas: as lições aprendidas ao longo de 25 anos e os desafios futuros. Washington, D.C.: OPS; 2003.

32. Lawn JE, Rohde J, Rifkin S, Were M, Paul VK, Chopra M. Alma-Ata 30 years on: revolutionary, relevant, and time to revitalise. Lancet 2008; 372(9642):917927.

33. Cohn A. Mudanças econômicas e políticas de saúde no Brasil. In: Laurell AC, organizadora. Estado e políticas sociais no neoliberalismo. São Paulo: Cortez; 1997. p. 225-244.

34. Organização M undial da Saúde. Conferencia Internacional sobre Atención Primaria de Salud: Declaración de Alma-Ata. Genebra: OM S; 1978.

35. Billings J, Anderson GM, N ewman LS. Recent findings on preventable hospitalizations. $\mathrm{H}$ ealth Aff (M illwood) 1996l; 15(3):239-249.

36. Clancy CM. The persistent challenge of avoidable hospitalizations. Health Serv Res 2005; 40(4):953956.

37. Caminal Homar J, Casanova M atutano C. La evaluación de la atención primaria y las hospitalizaciones por ambulatory care sensitive conditions. $\mathrm{M}$ arco conceptual. Aten Primaria 2003; 31(1):61-65.

38. Caminal J, Starfield B, Sanchez E, Casanova C, $M$ orales $M$. The role of primary care in preventing ambulatory care sensitive conditions. Eur J Public Health 2004; 14(3):246-251.

39. Ansari Z, Barbetti T, Carson NJ, Auckland MJ, Cicuttini F. The Victorian Ambulatory Care Sensitive Conditions study: rural and urban perspectives. Soz Praventivmed 2003; 48(1):33-43.

40. Lakhani A, Coles J, Eayres D, Spence C, Sanderson $C$. Creative use of existing clinical and health outcomes data to assess NHS performance in England: part 2-more challenging aspects of monitoring. BMJ 2005; 330(7506):1486-1492.
41. Nedel FB, Facchini LA, M artin M ateo M, Vieira LAS, Thumé E. Family Health Program and ambulatory care-sensitive conditions in Southern Brazil. Rev. Saude Publica 2008; 42(6):1041-1052.

42. Gérvas J, Caminal-Homar J. Las hospitalizaciones por Ambulatory Care Sensitive Conditions (ACSC) desde el punto de vista del médico de atención primaria. Rev Esp Salud Pública 2007; 81(1):7-13.

43. Bermudez $D$, Baker $L$. The relationship between SCHIP enrollment and hospitalizations for ambulatory care sensitive conditions in California. J H ealth Care Poor Underserved 2005; 16(1):96-110.

44. Roos LL, Walld R, Uhanova J, Bond R. Physician visits, hospitalizations, and socioeconomic status: Ambulatory Care Sensitive Conditions in a Canadian setting. Health Serv Res 2005; 40(4):1167-1185.

45. Murray CJL, López AD. Estimating causes of death: new methods and global and regional applications for 1990. In: Murray CJL, López AD, editors. The global burden of disease: a comprehensive assessment of mortality and disability from diseases, injuries and risk factors in 1990 and projected to 2020. Cambridge: H arvard University Press; 1996. p. 117-200.

46. Starfield B. Equity and health: a perspective on nonrandom distribution of health in the population. Rev. Panam. Salud Públ. / Pan Am. J. Public H ealth 2002; 12(6):384-387.

Artigo apresentado em 17/11/2008

Aprovado em 07/08/2009

Versão final apresentada em 25/09/2009 